\title{
PENGARUH PERSEPSI DAN RELIGIUSITAS NASABAH TERHADAP KEPUTUSAN MEMILIH PRODUK GADAI EMAS DI PT BANK SYARIAH MANDIRI KANTOR CABANG PEMBANTU MEDAN ISKANDAR MUDA
}

\author{
Tiara Sulaika Rohimi Harahap \\ Politeknik Negeri Medan \\ Email: tiarasulaika@gmail.com
}

\begin{abstract}
This research was conducted to determine the impact of customer's perception and religiosity on the decision making to choose a gold pawning product at PT Bank Syariah Mandiri Medan KCP Iskandar Muda and to find out the most dominant variable which effect the decision of choosing a gold pawning product at PT Bank Syariah Medan KCP Medan Iskandar Muda. The dependent variable in this study was the decision to choose while the independent variable consisted of perception and speech. The sample used in this study was 50 people. Data analysis method that used in this research is the multiple linear regression analysis, classic asumption test, $T$ test, $F$ test, coefficient of determination test. The results showed that perception and religiosity partially significantly influence customer decisions, also, perception and religiosity simultaneously have a significant effect on customer decisions. The most dominant variable which influence the decision to choose a product is perception with an $R$ Square value of $29.8 \%$, so that if customer perception continues to be improved it will affect the increase in the number of gold mortgage financing customers at Bank Syariah Mandiri Medan KCP Iskandar Muda.
\end{abstract}

Keywords: Perception, Religiosity, Decision to Choose

\begin{abstract}
Abstrak
Penelitian ini dilakukan untuk mengetahui pengaruh persepsi dan religiusitas nasabah terhadap keputusan memilih produk gadai emas di PT Bank Syariah Mandiri KCP Medan Iskandar Muda dan untuk mengetahui variabel yang paling dominan yang mempengaruhi keputusan memilih produk gadai emas di PT Bank Syariah Medan KCP Medan Iskandar Muda. Variabel dependen dalam penelitian ini adalah keputusan memilih sedangkan variabel independen terdiri dari persepsi dan religiusitas. Sampel yang digunakan dalam penelitian ini adalah sebanyak 50 orang. Metode analisis data yang digunakan adalah analisis regresi linear berganda, uji asumsi klasik, uji t, uji $F$ dan uji koefisien determinasi. Hasil penelitian menunjukkan bahwa persepsi dan religiusitas secara parsial berpengaruh signifikan terhadap keputusan nasabah, dan secara simultan persepsi dan religiusitas juga berpengaruh signifikan terhadap keputusan nasabah. Variabel yang paling dominan mempengaruhi keputusan memilih produk adalah adalah persepsi dengan nilai R Square sebesar 29,8\%, sehingga apabila persepsi nasabah terus ditingkatkan maka akan mempengaruhi peningkatan jumlah nasabah pembiayaan gadai emas pada Bank Syariah Mandiri KCP Medan Iskandar Muda.
\end{abstract}

Kata Kunci: Persepsi, Religiusitas, Keputusan Memilih 


\section{PENDAHULUAN}

Dalam menjalankan kegiatan usahanya bank syariah menawarkan bermacam-macam produk dan salah satunya adalah Gadai Emas.

"Gadai (rahn) merupakan perjanjian penyerahan barang yang digunakan sebagai agunan untuk mendapatkan fasilitas pembiayaan. Gadai (rahn) juga diartikan sebagai jaminan terhadap utang yang mungkin dijadikan sebagai pembayar kepada pemberi utang baik seluruhnya atau sebagian apabila pihak yang berutang tidak mampu melunasinya" (Ismail, 2015: 215).

Gadai Emas merupakan pembiayaan yang diberikan oleh bank syariah kepada nasabah yang membutuhkan dana dengan menggunakan emas sebagai jaminannya. Investasi emas kini menjadi tren dikalangan masyarakat. Masyarakat menggadaikan emas untuk memperoleh pembiayaan dari lembaga keuangan seperti perbankan maupun pegadaian. Salah satu keuntungan investasi emas adalah banyaknya fasilitas pembiayaan yang tersedia dan dapat digunakan sewaktu-waktu dengan cepat. Jika masyarakat membutuhkan uang dalam waktu segera, mereka bisa menggadaikan emas yang dimiliki tanpa harus kehilangan investasi mereka.

Transaksi gadai dihalalkan menurut Syariat Islam karena dalam transaksi gadai menggunakan akad rahn. Praktik gadai merupakan hal yang dianjurkan dalam Islam, sebagaimana yang telah difirmankan oleh Allah SWT dalam AlQur'an surah Al-Baqarah:283, yaitu:

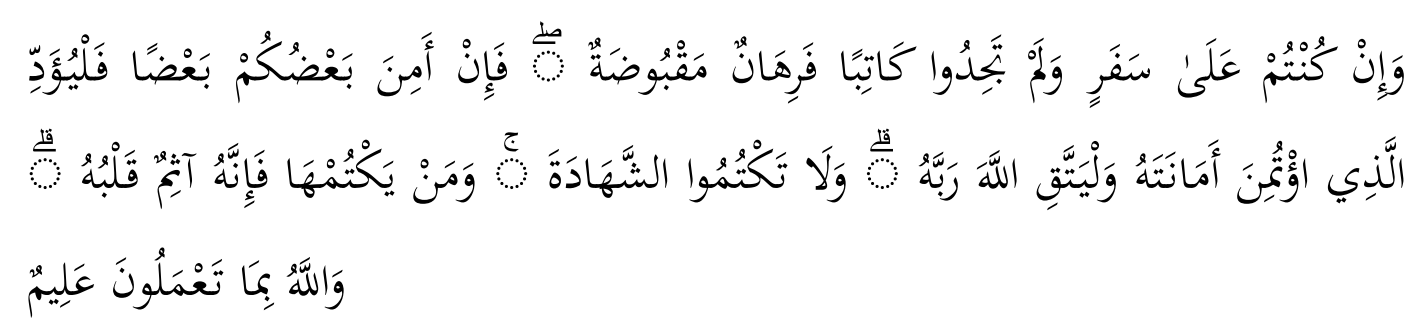

Artinya: jika kamu dalam perjalanan (dan bermu'amalah ttidak secara tunai) sedang kamu tidak memperoleh seorang penulis, maka hendaklahh ada barang tanggungan yang dipegang (oleh yang berpiutang). Akan teteapi jika sebagian kamu mempercayai sebagian yang lain, maka hendaklah yang dipercayai itu menunaikan amanatnya (hutangnya) dan hendaklah ia bertakwa kepada Allah Tuhannya, dan janganlah kamu (para saksi) menyembunyikan persaksian. Dan barangsiapa yang menyembunyikannya maka sesungguhnya ia adalah orang yang berdosa hatinya, dan Allah Maha mengetahui apa yang kamu kerjakan (QS. Al-Baqarah:283)

Ayat ini secara eksplisit menyebutkan "barang tanggungan yang dipegang (oleh yang berpiutang)". Dimana dalam dunia keuangan barang tanggungan biasa dikenal sebagai jaminan atau objek gadai. Praktik gadai juga telah ada sejak 
zaman Rasulullah SAW dan beliau sendiri yang pernah melakukannya sebagaimana dalam hadits berikut ini:

"Sesungguhnya Rasulullah SAW pernah membeli makanan dengan berutang dari seorang Yahudi, dan Nabi menggadaikan sebuah baju besi kepadanya." (HR. Buchori dan Muslim dari Aisyah Binti Abu Bakar)

Hadits ini menjelaskan bahwa kegiatan gadai sudah ada sejak zaman Rasulullah SAW. Berdasarkan hadits inilah, saat ini banyak lembaga-lembaga keuangan baik bank maupun lembaga keuangan non bank mulai menawarkan produk gadai.

Gadai emas merupakan produk inovasi dari lembaga keuangan syariah yang mendapat respon dari Majelis Ulama Indonesia (MUI) dengan mengeluarkan Fatwa Dewan Syariah Nasional MUI Nomor 26/DSN-MUI/III/2002 Tentang Gadai Emas dan membolehkan gadai emas menggunakan akad Rahn sesuai dengan Fatwa DSN MUI Nomor 25/DSN-MUI/III/2002 tentang Rahn. Fatwa DSN MUI Nomor 26/DSN-MUI/III/2002 mengatur tentang ongkos dan biaya penyimpanan barang (marhun) ditanggung oleh pegadai (rahin), namun fatwa ini memberikan batasan bahwa ongkos yang dibebankan kepada pegadai (rahin) besarnya didasarkan pada pengeluaran yang nyata-nyata diperlukan.

Berdasarkan fatwa ini bank syariah tidak diperbolehkan mengambil keuntungan dari akad qardh dan rahn, kecuali hanya sebatas mengambil biayabiaya yang nyata diperlukan saja. Akan tetapi ada penambahan akad yaitu ijarah atas penitipan barang gadai.

Bank Syariah Mandiri merupakan salah satu bank syariah di Indonesia yang menawarkan produk gadai emas. Hal ini disebabkan karena kebutuhan masyarakat akan pembiayaan emas senantiasa tumbuh dan berkembang sejalan dengan pertumbuhan ekonomi dan kegiatan bisnis (www. Iqtishadconsulting.com).

Layanan gadai emas di perbankan syariah mendapat animo yang cukup besar dari masyarakat. Hal ini dibuktikan dengan pertumbuhan omzet bisnis emas pada Bank Mandiri Syariah sebesar 21\% dari Rp6,72 triliun per Desember 2017 menjadi Rp8,11 triliun per Desember 2018 (m.kontan.co.id). Saat ini jumlah nasabah gadai emas yang terdapat di Bank Syariah Mandiri KCP Medan Iskandar Muda adalah sebanyak 283 orang. (Sumber: Bank Syariah Mandiri KCP Medan Iskandar Muda).

Persepsi adalah anggapan langsung atas sesuatu. Persepsi atau pandangan seseorang terhadap sesuatu dihasilkan dari informasi yang mereka dapatkan, hasil informasi tersebut dipahami selanjutnya konsumen akan menarik kesimpulan sehingga menciptakan sebuah penilaian terhadap sesuatu tersebut. Penumbuhan 
minat konsumen guna untuk menarik konsumen untuk menggunakan jasa yang dipromosikan maka harus bisa menimbulkan persepsi yang positif terhadap produk yang ditawarkan. (Zainal, 2014:326)

Heri Sudarsono (Ningsih, 2017:30) mengatakan bahwa Dalam kehidupan sehari-hari perilaku konsumen berbeda-beda. Dalam Islam perilaku konsumen harus mencerminkan hubungan dirinya dengan Allah SWT. Islam telah mengatur segenap perilaku manusia dalam memenuhi kebutuhan hidupnya yaitu tidak menyimpang dari ajaran agama Islam. Sehingga setiap manusia harus mampu memutuskan pilihan yang akan diambil tersebut sesuai dengan kebutuhan dan keinginnya dan tentunya tidak menyimpang dari ketentuan agama.

Dalam islam, perilaku seorang konsumen harus mencerminkan hubungan dirinya dengan Allah SWT, konsumen muslim lebih memilih jalan yang dibatasi Allah dengan tidak memilih barang haram, tidak kikir, dan tidak tamak supaya kehidupannya selamat baik di dunia maupun di akhirat.

Religiusitas adalah suatu sikap atau kesadaran yang muncul yang didasarkan atas keyakinan atau kepercayaan seseorang terhadap suatu agama. Sikap keagamaan merupakan suatu keadaan yang ada pada diri seseorang yang mendorongnya untuk bertingkah laku sesuai dengan kadar ketaatannya terhadap agama. (Jalaluddin, 2010:257)

Masyarakat yang memiliki religiusitas tinggi tentu akan cenderung berpaling kepada ajaran-ajaran agama dalam melakukan kegiatan transaksi. Motif untung dan rugi secara ekonomi memang sangat penting dalam menjalankan praktek bisnis. (Wibowo, 2015).

Pada kenyataannya mayoritas nasabah perbankan syariah merupakan nasabah yang mengedepankan motif keuntungan, sehingga dapat berpindah ketika suku bunga simpanan di bank konvensional lebih menguntungkan. Hal ini didukung dengan penelitian dari (Andri Perdana, 2018) yang menyatakan bahwa nilai taksiran dari produk gadai emas di PT Bank Syariah Mandiri mempunyai pengaruh yang signifikan dan positif terhadap keputusan nasabah untuk melakukan take over gadai emas pada Bank Syariah Mandiri KCP Medan Iskandar Muda.

Kelompok nasabah ini biasanya mempunyai rekening ganda, baik di bank syariah maupun di bank konvensional, sehingga dapat dengan mudah melakukan tindakan arbitrase. Hanya sekitar 20 persen nasabah yang benar-benar loyal menggunakan produk-produk di bank syariah karena alasan religius. (Shofwa,2016:4). 
Produk gadai emas sangatlah menguntungkan karena dengan memanfaatkan nilai gadai emas, nasabah dapat menerima biaya yang dapat dikelola baik untuk kebutuhan hidup sehari-hari hingga untuk kebutuhan bisnis. Produk gadai emas syariah mulai banyak dilirik nasabah sebagai alternatif sumber pembiayaan. Sejumlah penyedia jasa gadai emas syariah mengaku pengguna jasa ini tumbuh signifikan selama beberapa bulan belakangan.

Nasabah mulai banyak melirik produk ini karena bisa dijadikan sebagai alternatif sumber pembiayaan, dan menjadi salah satu produk unggulan di Bank Syariah Mandiri. Walaupun masih banyak masyarakat yang memandang miring bank syariah beserta produk-produknya, dengan menganggap perbankan syariah tidak ada bedanya dengan bank konvensional. Hal ini dibuktikan dengan ada masyarakat yang beranggapan bahwa yang menjadi pembeda antara bank konvensional dengan bank syariah hanya di teori saja, sementara untuk penerapan atau implementasinya tidak ada perbedaan diantara keduanya.

Struktur pengetahuan dan persepsi masyarakat yang sudah terbangun sejak lama tentu saja tidak mudah untuk diarahkan kepada hanya perbankan yang bersaskan syariah Islam. Fenomena yang terjadi bahwa persepsi terhadap bank syariah dalam aplikasinya sama dengan bank konvensional. Hal ini disebabkan kurangnya pemahaman masyarakat tentang produk bank syariah serta minimnya edukasi yang mereka dapatkan melalui media-media promosi seperti televisi, media cetak dan media sosial. Promosi yang dilakukan oleh bank syariah kurang dapat menyentuh masyarakat bahkan masih sedikit informasi yang mereka terima dari promosi ini.

Dalam penelitiannya (Muhammad Zuhirsyan dan Nurlinda, 2017) menyatakan bahwa persepsi berpengaruh tidak signifikan terhadap keputusan memilih bank syariah. Sementara pada penelitian Julia Sri Ningsih (2017) mengatakan bahwa persepsi berpengaruh signifikan terhadap keputusan memilih bank syariah.

Berangkat dari paradigma diatas, maka penulis merasa tertarik untuk mengadakan penelitian tentang persepsi dan religiusitas nasabah terhadap keputusan memilih produk pembiayaan gadai emas, penelitian ini akan dilakukan pada Bank Syariah Mandiri Kantor Cabang Pembantu Medan Iskandar Muda.

Maka dari itu penelitian ini diberi judul: "Pengaruh Persepsi Dan Religiusitas Nasabah Terhadap Keputusan Memilih Produk Gadai Emas Di PT. Bank Syariah Mandiri Kantor Cabang Pembantu Medan Iskandar Muda” 


\section{METODE PENELELITIAN}

Dalam penelitian ini, penulis menggunakan metode penelitian kuantitatif. Penelitian kuantitatif merupakan penelitian yang menggunakan data yang diukur dalam suatu skala angka. Tujuan penelitian kuantitatif yaitu untuk mengembangkan dan menggunakan model matematis, teori dan/atau hipotesis yang berkaitan dengan fenomena yang diamati oleh penulis.

Variabel bebas (independent variable) yang digunakan dalam penelitian ini adalah persepsi dan religiusitas, sedangkan yang menjadi variabel terikat (dependent variable) adalah keputusan nasabah. Variabel tersebut ditentukan berdasarkan kajian secara teori dan observasi yang dilakukan oleh penulis. Selanjutnya penulis menetapkan rumusan masalah dan hipotesis penelitian. Kemudian menentukan data yang akan digunakan dan cara memperolehnya. Setelah itu penulis mulai melakukan analisis terhadap permasalahan yang diteliti dan mendapatkan jawaban dari permasalahan tersebut dan dilanjutkan dengan membuat kesimpulan akhir penelitian

Tabel 1. Defenisi Operasional Variabel

\begin{tabular}{lll}
\hline $\begin{array}{l}\text { No. } \\
\text { Variabel }(\mathbf{X} \\
\text { dan } \mathbf{~})\end{array}$ & Dimensi & Indikator \\
\hline $\begin{array}{l}\text { Persepsi } \\
\left(\mathrm{X}_{1}\right)\end{array}$ & Perceiver & $\begin{array}{l}\text { Interprestasi terhadap hal-hal yang } \\
\text { terjadi di lingkungan. }\end{array}$ \\
& Target & $\begin{array}{l}\text { Hal yang mempengaruhi terciptanya } \\
\text { persepsi, seperti motivasi dan latar } \\
\text { belakang }\end{array}$ \\
& Situation & Situasi yang terjadi saat sedang \\
& & \\
& &
\end{tabular}




\begin{tabular}{|c|c|c|c|}
\hline No. & $\begin{array}{l}\text { Variabel (X dan } \\
\text { Y) }\end{array}$ & Dimensi & Indikator \\
\hline \multirow[t]{5}{*}{2.} & $\operatorname{Religiusitas}\left(\mathrm{X}_{2}\right)$ & Iman & $\begin{array}{l}\text { Kepercayaan kepada Allah SWT, } \\
\text { melakukan praktek-praktek } \\
\text { peribadatan yang sesuai dengan nilai- } \\
\text { nilai islam }\end{array}$ \\
\hline & & Islam & $\begin{array}{l}\text { Melaksanakan kewajiban-kewajiban } \\
\text { ritual dalam agama untuk } \\
\text { menunjukkan komitmen seseorang } \\
\text { dalam agama yang dianutnya. }\end{array}$ \\
\hline & & Ihsan & $\begin{array}{l}\text { Selalu mengaplikasikan ajaran islam } \\
\text { dimanapun dan apapun hal atau } \\
\text { kegiatan yang dilakukan }\end{array}$ \\
\hline & & Ilmu & $\begin{array}{l}\text { Pengetahuan tentang Al-Qur'an, } \\
\text { pokok-pokok ajaran yang harus } \\
\text { diimani, dan pemahaman terhadap } \\
\text { kaidah ekonomi islam / perbankan } \\
\text { syariah }\end{array}$ \\
\hline & & Amal & $\begin{array}{l}\text { Mengukur sejauh mana perilaku } \\
\text { seseorang yang dimotivasi oleh } \\
\text { ajaran-ajaran agama dalam kehidupan } \\
\text { sosial }\end{array}$ \\
\hline \multirow[t]{3}{*}{3.} & Keputusan & Benefit Association & $\begin{array}{l}\text { Menyesuaikan produk dengan } \\
\text { kebutuhan consumer }\end{array}$ \\
\hline & Pembelian (Y) & $\begin{array}{l}\text { Prioritas dalam } \\
\text { membeli }\end{array}$ & $\begin{array}{l}\text { Memberikan produk yang unggul } \\
\text { bagi consumer }\end{array}$ \\
\hline & & Frekuensi pembelian & $\begin{array}{l}\text { Menciptakan kesan yang baik dalam } \\
\text { pandangan consumer tentang produk } \\
\text { yang diberikan }\end{array}$ \\
\hline
\end{tabular}

Sumber: Olahan dari berbagai sumber 


\section{HASIL DAN PEMBAHASAN}

\section{Karakteristik Responden}

Data karakteristik responden digunakan untuk melihat gambaran nasabah yang menjadi responden dalam penelitian ini, yang kemudian akan diklasifikasikan berdasarkan jenis kelamin, usia, agama, dan pekerjaan.

\section{1) Karakteristik Responden Berdasarkan Jenis Kelamin}

Berdasarkan data yang dikumpulkan dari responden, maka dapat diperoleh data mengenai jenis kelamin responden sebagai berikut:

Tabel 2. Jenis Kelamin Responden

\begin{tabular}{|c|c|c|c|c|c|}
\hline \multicolumn{6}{|c|}{ JENIS KELAMIN } \\
\hline & & & & & Cumulative \\
\hline & & Frequency & Percent & Valid Percent & Percent \\
\hline \multirow[t]{3}{*}{ Valid } & Laki-Laki & 14 & 27.5 & 28.0 & 28.0 \\
\hline & Perempuan & 36 & 71.6 & 72.0 & 100.0 \\
\hline & Total & 50 & 100.0 & 100.0 & \\
\hline
\end{tabular}

Sumber: Data diolah dengan SPSS 23

Berdasarkan tabel 2 dapat dilihat bahwa responden dengan jenis kelamin laki-laki berjumlah 14 orang atau sebesar 27,5\%, sedangkan responden dengan jenis kelamin perempuan berjumlah 36 orang atau sebesar $70,6 \%$. Hal ini menunjukkan bahwa responden yang paling dominan adalah responden dengan jenis kelamin perempuan.

\section{2) Karakteristik Responden Berdasarkan Usia}

Berdasarkan data yang dikumpulkan dari responden, maka dapat diperoleh data mengenai usia responden sebagai berikut:

Tabel 3. Usia Responden

\begin{tabular}{rlrrrr} 
& & & & \multicolumn{2}{c}{ Cumulative } \\
\multirow{3}{*}{ Valid } & Frequency & Percent & Valid Percent & Percent \\
\cline { 3 - 6 } & 20-35 Tahun & 16 & 31.4 & 32.0 & 32.0 \\
& 35-50 Tahun & 31 & 60.8 & 62.0 & 94.0 \\
& >50 Tahun & 3 & 5.9 & 6.0 & 100.0 \\
& Total & 50 & 100.0 & 100.0 & \\
\hline
\end{tabular}

Sumber: Data diolah dengan SPSS 23

Berdasarkan tabel 3 dapat dilihat bahwa responden dengan usia 20-35 tahun berjumlah 16 orang atau sebesar 31,4\%, responden dengan usia 35-50 tahun berjumlah 31 orang atau sebesar $60,8 \%$ dan responden dengan usia $>50$ tahun berjumlah 3 orang atau sebesar 5,9\%. Hal ini menunjukkan bahwa responden yang paling dominan adalah responden dengan usia 35-50 tahun yaitu sebanyak 31 orang. 


\section{3) Karakteristik Responden Berdasarkan Agama}

Berdasarkan data yang dikumpulkan dari responden, maka dapat diperoleh data mengenai agama responden sebagai berikut:

Tabel 4. Agama Responden

\begin{tabular}{|c|c|c|c|c|c|}
\hline & & Frequency & Percent & Valid Percent & $\begin{array}{c}\text { Cumulative } \\
\text { Percent }\end{array}$ \\
\hline Valid & Islam & 50 & 100 & 100.0 & 100.0 \\
\hline Total & & 50 & 100.0 & & \\
\hline
\end{tabular}

Sumber: Data diolah dengan SPSS 23

Berdasarkan tabel 4 dapat dilihat bahwa responden yang beragama islam berjumlah 50 orang atau sebesar 100\%. Hal ini menunjukkan bahwa responden yang paling dominan adalah responden yang beragama islam.yaitu sebanyak 50 orang.

\section{4) Karakteristik Responden Berdasarkan Pekerjaan}

Berdasarkan data yang dikumpulkan dari responden, maka dapat diperoleh data mengenai pekerjaan responden sebagai berikut:

Tabel 5. Pekerjaan Responden

\begin{tabular}{llrrrr}
\hline & & & \multicolumn{2}{c}{ Cumulative } \\
& & Frequency & Percent & Valid Percent & Percent \\
\hline Valid & Pegawai Negeri & 8 & 15.7 & 16.0 & 16.0 \\
& Wiraswasta & 12 & 23.5 & 24.0 & 40.0 \\
& Karyawan Swasta & 20 & 39.2 & 40.0 & 80.0 \\
& Lain-Lain & 10 & 19.6 & 20.0 & 100.0 \\
& Total & 50 & 100 & 100.0 & \\
\hline & & & Sumber: Data diolah dengan SPSS 23
\end{tabular}

Berdasarkan tabel 5 dapat dilihat bahwa responden yang bekerja sebagai pegawai negeri berjumlah 8 orang atau sebesar $15,7 \%$, responden yang bekerja sebagai wiraswasta berjumlah 12 orang atau sebesar $23,5 \%$ dan responden yang bekerja sebagai karyawan swasta berjumlah 20 orang atau sebesar 39,2\% dan sisanya adalah lain lain berjumlah 10 orang atau sebesar 19,6\%. Hal ini menunjukkan bahwa responden yang paling dominan adalah responden yang bekerja sebagai karyawan swasta yaitu sebanyak 20 orang.

\section{Uji Validitas}

Berdasarkan penjelasan pada bab 3, setiap kuesioner harus dilakukan uji validitas untuk mengetahui apakah setiap butir pertanyaan tersebut valid atau tidak. Dalam penelitian ini pengujian validitas menggunakan korelasi pearson dan 
menggunakan bantuan program SPSS Versi 23. Setiap butir pernyataan dikatakan valid apabila $r$ hitung $>r$ tabel. Jumlah sampel dalam penelitian ini adalah sebesar 50 , sehingga jumlah df dapat dihitung dengan rumus $\mathrm{df}=\mathrm{n}-2$, maka $\mathrm{df}=50-2=$ 48 dengan besar alpha 5\% $(0,05)$ sehingga dapat diperoleh $r$ tabel sebesar 0,2787 atau dengan kata lain nilai korelasi masing-masing butir pernyataan harus lebih besar dari 0,2787. Setelah dilakukan uji validitas, maka dapat diketahui bahwa 21 butir pernyataan pada penelitian ini valid karena nilai korelasinya > 0,2787. Berikut adalah hasil dari uji validitas:

Tabel 6. Hasil Uji Validitas

\begin{tabular}{|c|c|c|c|c|}
\hline Variabel & Pernyataan & Korelasi & r tabel & Keterangan \\
\hline \multirow{9}{*}{$\begin{array}{l}\text { Persepsi } \\
\text { (X1) }\end{array}$} & persepsi1 & 0,332 & 0,2787 & Valid \\
\hline & persepsi2 & 0,290 & & Valid \\
\hline & persepsi3 & 0,379 & & Valid \\
\hline & persepsi4 & 0,488 & & Valid \\
\hline & persepsi5 & 0,411 & & Valid \\
\hline & persepsi6 & 0,557 & & Valid \\
\hline & persepsi7 & 0,598 & & Valid \\
\hline & persepsi8 & 0,725 & & Valid \\
\hline & persepsi9 & 0,606 & & Valid \\
\hline \multirow{10}{*}{$\begin{array}{l}\text { Religiusitas } \\
\text { (X2) }\end{array}$} & religiusitas 1 & 0,743 & & Valid \\
\hline & religiusitas2 & 0,593 & & Valid \\
\hline & religiusitas3 & 0,716 & & Valid \\
\hline & religiusitas4 & 0,744 & 0,2787 & Valid \\
\hline & religiusitas5 & 0,448 & & Valid \\
\hline & religiusitas6 & 0,637 & & Valid \\
\hline & religiusitas 7 & 0,700 & & Valid \\
\hline & religiusitas8 & 0,685 & & Valid \\
\hline & religiusitas9 & 0,511 & & Valid \\
\hline & religiusitas 10 & 0,549 & & Valid \\
\hline \multirow{9}{*}{$\begin{array}{l}\text { Keputusan } \\
\text { Memilih } \\
\text { (Y) }\end{array}$} & keputusan1 & 0,458 & 0,2787 & Valid \\
\hline & keputusan2 & 0,300 & & Valid \\
\hline & keputusan3 & 0,380 & & Valid \\
\hline & keputusan4 & 0,394 & & Valid \\
\hline & keputusan5 & 0,543 & & Valid \\
\hline & keputusan6 & 0,536 & & Valid \\
\hline & keputusan7 & 0,589 & & Valid \\
\hline & keputusan8 & 0,584 & & Valid \\
\hline & keputusan9 & 0,527 & & Valid \\
\hline
\end{tabular}




\section{Uji Reliabilitas}

Uji reliabilitas hanya dapat dilakukan setelah suatu instrumen telah dipastikan validitasnya. Pengujian reliabilitas dalam penelitian ini untuk menunjukan tingkat reliabilitas konsistensi internal teknik yang digunakan adalah dengan mengukur koefisien Cronbach's Alpha dengan bantuan program SPSS 23. Suatu pernyataan dapat dikategorikan reliabel jika nilai alpha lebih besar dari 0,60 . Setelah dilakukan uji reliabilitas hasil yang diperoleh adalah sebagai berikut:

Tabel 7. Hasil Uji Reliabilitas

\begin{tabular}{lccc}
\hline \multicolumn{1}{c}{ Variabel } & Cronbach's Alpha & N of items & Keterangan \\
\hline Persepsi & 0,610 & 9 & Reliabel \\
Religiusitas & 0,828 & 10 & Reliabel \\
Keputusan & 0,616 & 9 & Reliabel \\
Memilih & & &
\end{tabular}

Sumber: data diolah dengan SPSS 23

\section{Uji Asumsi Klasik}

\section{1) Uji Normalitas}

\section{Analisis Grafik Normal P- P Plot}

Uji normalitas digunakan untuk menguji apakah dalam suatu model regresi linear variabel terikat dan variabel bebas keduanya mempunyai distribusi secara normal atau tidak (Ghozali, 2017:163). Uji Normalitas ini menggunakan pendekatan grafik yaitu grafik histogram dan grafik P-P plot. Dasar pengambilan keputusan menurut Ghozali (2017:170) adalah sebagai berikut:

a. Jika data menyebar di sekitar garis diagonal dan mengikuti arah garis diagonal atau grafik histogramnya menunjukkan pola distribusi normal, maka model regresi memenuhi asumsi normalitas.

b. Jika data menyebar jauh dari garis diagonal atau tidak mengikuti arah garis diagonal atau grafik histogramnya tidak menunjukkan pola distribusi normal, maka model regresi tidak memenuhi asumsi normalitas. 
Berikut ini adalah hasil dari uji normalitas:

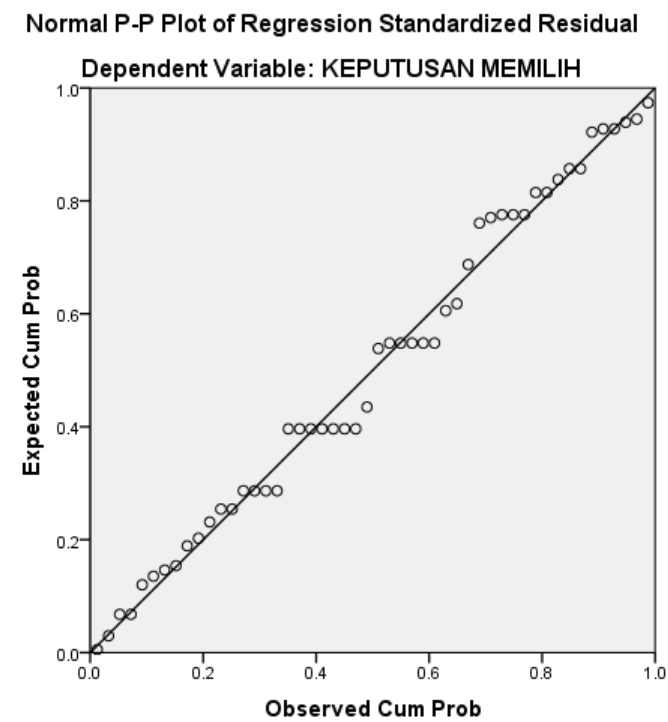

Gambar 1. Hasil Uji Normalitas dengan Normal P-P Plot

Berdasarkan gambar 1, menunjukkan bahwa data menyebar di sekitar garis diagonal dan mengikuti arah garis diagonal atau grafik histogramnya menunjukkan pola distribusi normal, maka model regresi memenuhi asumsi normalitas.

\section{Analisis Histogram}

Uji normalitas juga dapat dilihat melalui Histogram. Data dapat dikatakan berdistribusi normal apabila kurva menggambarkan bentuk seperti lonceng. Berikut ini adalah hasil uji normalitas menggunakan Histogram:

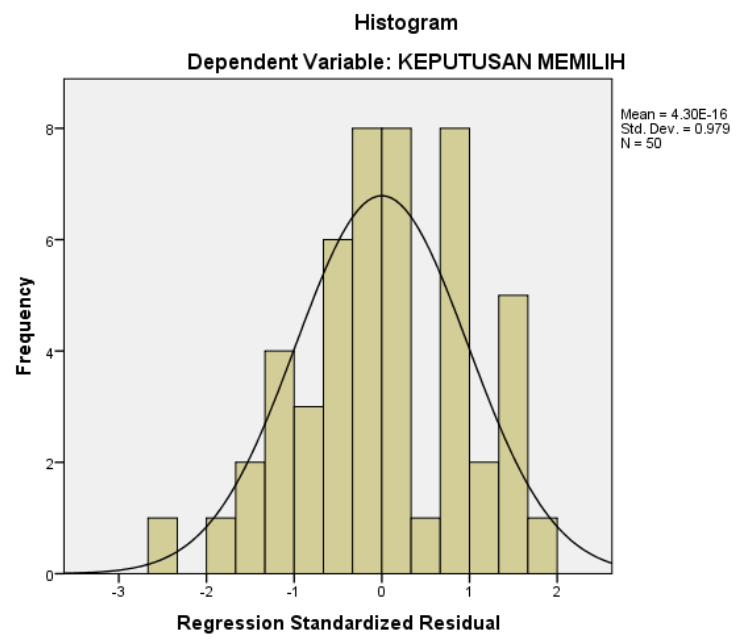

Gambar 2. Hasil Uji Normalitas dengan Histogram 
Berdasarkan gambar 2 histogram dapat dilihat bahwa kurva membentuk seperti lonceng, maka nilai residual tersebut dinyatakan normal atau data berdistribusi normal.

\section{Uji Multikolinearitas}

Istilah multikolinearitas (kolinearitas ganda) pertama kali ditemukan oleh Ragnar Frisch, yang berarti adanya hubungan linear yang sempurna atau pasti diantara beberapa atau semua variabel bebas dari model regresi berganda (Setiawan \& Kusrini, 2010:82). Uji multikolinearitas adalah untuk melihat ada atau tidaknya korelasi yang tinggi antara variabel-variabel bebas dalam suatu model regresi linear berganda. Untuk menguji multikolinearitas dapat dilihat dari nilai Tolerance dan Variance Inflation Factor (VIF). Apabila nilai Tolerance > 0,01 atau nilai VIF $<10$ maka model regresi terbebas dari masalah multikolinearitas. Berikut ini adalah hasil uji multikolinearitas:

Tabel 8. Hasil Uji Multikolinearitas

\begin{tabular}{llcr}
\hline \multicolumn{3}{l}{ Model } & \multicolumn{3}{c}{ Coefficients $^{\mathbf{a}}$ Collinearity } & Statistics \\
& & Tolerance & VIF \\
\hline $1 \quad$ (Constant) & .426 & 2.347 \\
& Persepsi & .426 & 2.347 \\
& Religiulitas & \multicolumn{3}{c}{ Sumber: Data diolah dengan SPSS 23 }
\end{tabular}

Berdasarkan tabel 8 dapat dilihat bahwa nilai Tolerance masing-masing variabel adalah $>0,01$ dan nilai VIF masing-masing variabel adalah $<10$ maka dapat disimpulkan bahwa persamaan regresi tidak mengalami masalah multikolinearitas.

\section{Uji Heterokedastisitas}

Uji heteroskedastisitas bertujuan untuk menguji apakah dalam model regresi terjadi ketidaksamaan variance dari residual satu pengamatan yang lain. Heteroskedastisitas menunjukan bahwa variasi variabel tidak sama untuk semua pengamatan. Pada heteroskedastisitas kesalahan yang terjadi tidak secara acak tetapi menunjukan hubungan yang sistematis sesuai dengan besarnya satu atau lebih variabel. Berdasarkan hasil pengolahan data, maka hasil Scatterplot dapat dilihat pada gambar 3: 


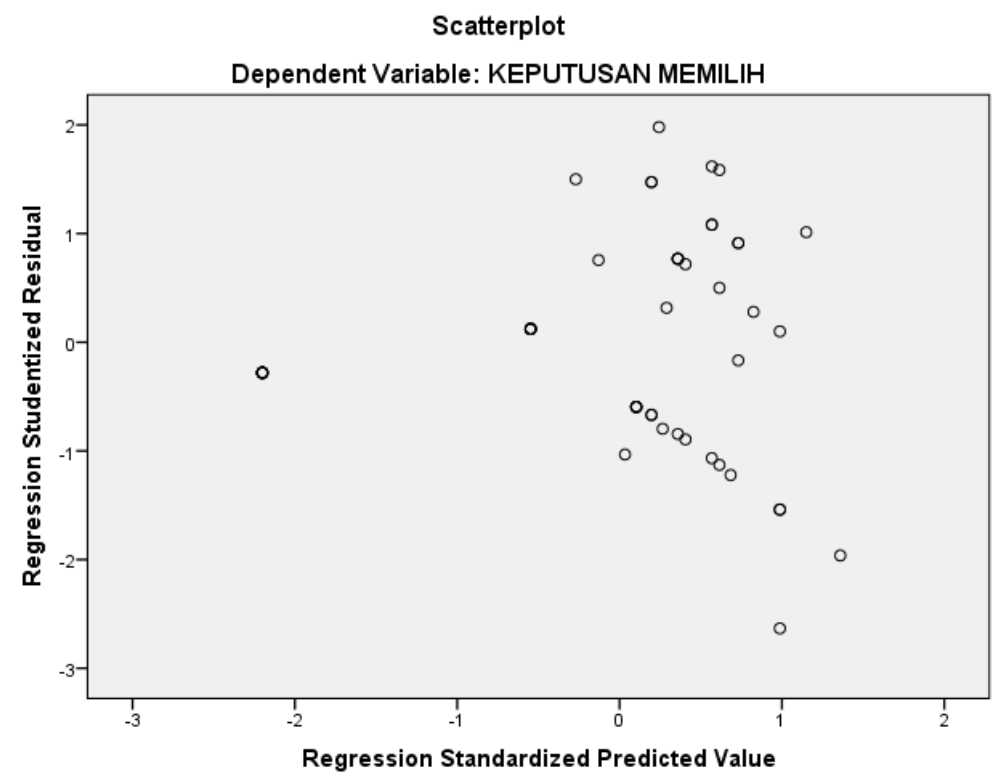

Gambar 3. Hasil Uji Heterokedastisitas

Berdasarkan gambar 3 dapat dilihat bahwa tidak ada pola yang jelas, serta titik-titik menyebar di atas dan di bawah angka 0 pada sumbu Y, maka tidak terjadi masalah heterokedastisitas.

\section{Analisis Regresi Linear Berganda}

Analisis regresi linear berganda digunakan untuk melihat seberapa besar pengaruh variabel independen terhadap variabel dependen dalam penelitian. Variabel independen yang digunakan adalah persepsi dan religiusitas, sedangkan variabel dependen yang digunakan dalam penelitian ini adalah keputusan memilih produk gadai emas. Hasil pengolahan data analisis regresi berganda dengan program SPSS 23 adalah sebagai berikut:

Tabel 9. Hasil Analisis Regresi Berganda

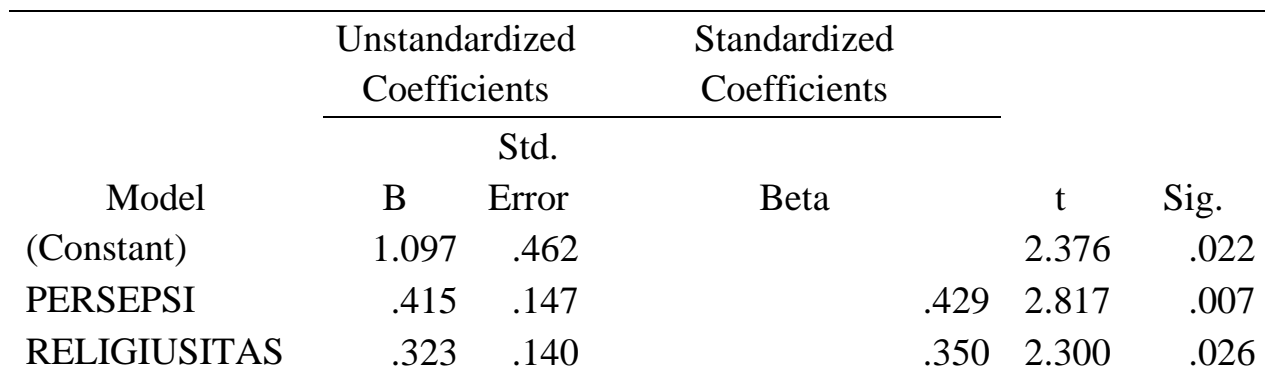

a. Dependent Variable: Keputusan Memilih 
Berdasarkan tabel 9 hasil analisis regresi linear berganda di atas, maka persamaan regresi dalam penelitian ini adalah:

Keputusan Memilih = 1,097 + 0,415 Persepsi + 0,323 Religiusitas

Dari rumus regresi di atas dapat dinyatakan nilai koefisien regresinya sebagai berikut:

1. Nilai konstanta sebesar 1,097 menyatakan bahwa jika tidak ada nilai persepsi dan religiusitas maka besarnya keputusan memilih sebesar 1,097.

2. Apabila nilai persepsi mengalami kenaikan sebesar 1 satuan maka nilai keputusan memilih akan mengalami kenaikan sebesar 0,415.

3. Apabila nilai religiusitas mengalami kenaikan sebesar 1 satuan maka nilai keputusan memilih akan mengalami kenaikan sebesar 0,323 .

\section{Uji Hipotesis}

\section{Uji t}

Uji statistik $\mathrm{t}$ berguna untuk menguji pengaruh dari masing-masing variabel independen secara parsial terhadap variabel dependen. Untuk mengetahui ada atau tidaknya pengaruh masing-masing variabel independen secara parsial terhadap variabel dependen dapat dilihat pada tingkat signifikansi 0,05. Hasil uji t dapat dilihat pada tabel 10 :

Tabel 10. Hasil Uji t

\section{Coefficients $^{\mathrm{a}}$}

\begin{tabular}{cccccc}
\hline \multicolumn{7}{c}{$\begin{array}{c}\text { Unstandardized } \\
\text { Coefficients }\end{array}$} & $\begin{array}{c}\text { Standardized } \\
\text { Coefficients } \\
\text { Model }\end{array}$ & $\mathrm{B}$ & Std. Error & Beta & $\mathrm{t}$ & Sig. \\
\cline { 2 - 6 } (Constant) & 1.09 & .462 & & 2.376 & .022 \\
& 7 & & & & \\
PERSEPSI & .415 & .147 & .429 & 2.817 & .007 \\
RELIGIUSITAS & .323 & .140 & .350 & 2.300 & .026 \\
\hline a. Dependent Variable: KEPUTUSAN MEMILIH
\end{tabular}

Sumber: Data diolah dengan SPSS 23

Berdasarkan tabel 10, besarnya pengaruh masing-masing variabel independen secara parsial terhadap variabel dependen dapat dijelaskan sebagai berikut:

1. Pengaruh Persepsi terhadap Keputusan Memilih

Berdasarkan tabel koefisien di atas dapat diketahui bahwa t hitung variabel Persepsi sebesar 2,817. Tabel distribusi t dicari pada tingkat kepercayaan $\alpha$ $=5 \%$ dengan derajat kebebasan (df) $(n-k-1)$ atau $(50-2-1)=47$, maka diperoleh nilai $t$ sebesar 2.011. Karena t hitung $>\mathrm{t}$ tabel atau 2,817 > 2,011 maka H0 ditolak dan Ha diterima, yang berarti Persepsi berpengaruh 
signifikan terhadap Keputusan Memilih produk gadai emas. Variabel Persepsi mempunyai nilai probabilitas (sig) lebih kecil dari nilai $(\alpha)$ yaitu $0,007<0,05$ maka H0 ditolak yang artinya variable Persepsi mempunyai pengaruh signifikan terhadap Keputusan Memilih produk gadai emas.

2. Pengaruh Religiusitas terhadap Keputusan Memilih

Berdasarkan tabel koefisien di atas dapat diketahui bahwa t hitung variabel Religiusitas sebesar 2,300. Tabel distribusi t dicari pada tingkat kepercayaan $\alpha=5 \%$ dengan derajat kebebasan (df) (n-k-1) atau (50-2-1) = 47, maka diperoleh nilai $t$ sebesar 2,011. Karena $t$ hitung $>t$ tabel atau 2,300 > 2,011 maka H0 ditolak dan Ha diterima, yang berarti Religiusitas berpengaruh signifikan terhadap Keputusan memilih produk gadai emas. Variabel Pelayanan mempunyai nilai probabilitas (sig) lebih kecil dari nilai $(\alpha)$ yaitu $0,026<0,05$ maka H0 ditolak yang artinya variabel religiusitas mempunyai pengaruh signifikan terhadap keputusan memilih produk gadai emas di PT Bank Syariah Mandiri KCP Medan Iskandar Muda.

\section{Uji F}

Uji $\mathrm{F}$ dilakukan dengan tujuan untuk melihat pengaruh variable persepsi dan religiusitas terhadap keputusan memilih produk gadai emas secara simultan. Hasil yang diperoleh dari uji $\mathrm{F}$ adalah sebagai berikut:

Tabel 11. Hasil Uji F

\begin{tabular}{|c|c|c|c|c|c|c|}
\hline \multicolumn{7}{|c|}{ ANOVA $^{\text {a }}$} \\
\hline Model & & $\begin{array}{l}\text { Sum of } \\
\text { Squares }\end{array}$ & $\mathrm{df}$ & Mean Square & $\mathrm{F}$ & Sig. \\
\hline \multirow[t]{3}{*}{1} & Regression & 1.926 & 2 & .963 & 27.042 & $.000^{\mathrm{b}}$ \\
\hline & Residual & 1.674 & 47 & .036 & & \\
\hline & Total & 3.600 & 49 & & & \\
\hline
\end{tabular}

a. Dependent Variable: KEPUTUSAN MEMILIH

b. Predictors: (Constant), RELIGIUSITAS, PERSEPSI

Sumber: Data diolah dengan SPSS 23

Berdasarkan tabel 11, diperoleh $\mathrm{F}$ hitung sebesar 27,042. Tabel distribusi F dicari pada tingkat kepercayaan $\alpha=5 \%$, df1 (k-1) atau (3-1) = 2 dan df2 (n-k) atau 50-2 = 48 maka diperoleh nilai $\mathrm{F}$ tabel sebesar 3,19. F hitung $>\mathrm{F}$ tabel yaitu 27,042 > 3,19 maka H0 ditolak dan Ha diterima, sehingga dapat disimpulkan bahwa variabel persepsi dan religiusitas secara simultan berpengaruh signifikan terhadap keputusan memilih produk gadai emas.

Jika dilihat dari nilai probabilitas (Sig) diketahui bahwa nilai signifikansi lebih kecil dari 0,05 yaitu $0,000<0,05$ sehingga memiliki kesimpulan yang sama 
bahwa variabel persepsi dan religiusitas secara simultan berpengaruh signifikan terhadap keputusan memilih produk gadai emas.

\section{Koefisien Determinasi}

Untuk menentukan seberapa besar variabel independen dapat menjelaskan variabel dependen, maka perlu diketahui nilai koefisien determinasi (Adjusted $\mathrm{R}$ Square). Adapun hasil uji determinasi Adjusted R Square adalah sebagai berikut:

Tabel 12. Hasil Uji Koefisien Determinasi

\begin{tabular}{|c|c|c|c|c|}
\hline \multirow[b]{2}{*}{ Model } & \multirow[b]{2}{*}{$\mathbf{R}$} & \multicolumn{3}{|c|}{ Model Summary ${ }^{\mathbf{b}}$} \\
\hline & & R Square & $\begin{array}{l}\text { Adjusted R } \\
\text { Square }\end{array}$ & $\begin{array}{l}\text { Std. Error of } \\
\text { the Estimate }\end{array}$ \\
\hline 1 & $.931^{\mathrm{a}}$ & .535 & .515 & .18872 \\
\hline
\end{tabular}

Sumber: Data diolah dengan SPSS 23

Hasil pengujian menunjukkan besarnya koefisien korelasi berganda (R), koefisien determinasi ( $R$ Square), dan koefisien determinasi yang disesuaikan (Adjusted $R$ Square). Berdasarkan tabel model summary di atas diperoleh bahwa nilai koefisien korelasi berganda $(\mathrm{R})$ sebesar 0,731. Ini menunjukkan bahwa variabel persepsi dan religiusitas terhadap keputusan memilih mempunyai hubungan yang sangat kuat. Hasil pada tabel di atas juga menunjukkan bahwa nilai koefisien determinasi ( $R$ Square) sebesar 0,535. Hal ini berarti 53,5\% variasi dari keputusan memilih bisa dijelaskan oleh variasi variabel independen (persepsi dan religiusitas). Sedangkan sisanya $(100 \%-53,5 \%=4,35 \%)$ dijelaskan oleh variabel lain yang tidak dimasukkan dalam model penelitian ini. Jadi terdapat banyak variabel-variabel yang dapat mempengaruhi keputusan memilih produk gadai emas di PT Bank Syariah Mandiri KCP Medan Iskandar Muda.

\section{PEMBAHASAN}

\section{Pengaruh Persepsi terhadap Keputusan Memilih}

Apabila tingkat signifikansi lebih kecil dari 0,05 dan t hitung lebih besar dari t tabel, maka variabel independen berpengaruh terhadap variabel dependen. Berdasarkan hasil penelitian ini diperoleh tingkat signifikansi variabel persepsi sebesar 0,007 yang artinya lebih kecil dari 0,05 $(0,007<0,05)$ dan t hitung sebesar 2,817 lebih besar dibandingkan t tabel 2,011 (2,817> 2,011), maka dapat disimpulkan bahwa variabel persepsi berpengaruh signifikan terhadap keputusan memilih produk gadai emas di PT Bank Syariah Medan Iskandar Muda 


\section{Pengaruh Religiusitas terhadap Keputusan Memilih}

Apabila tingkat signifikansi lebih kecil dari 0,05 dan t hitung lebih besar dari $t$ tabel, maka variabel independen berpengaruh terhadap variabel dependen. Berdasarkan hasil penelitian ini diperoleh tingkat signifikansi variabel nilai religiusitas sebesar 0,026 yang artinya lebih kecil dari $0,05(0,026<0,05)$ dan $\mathrm{t}$ hitung sebesar 2,300 lebih besar dibandingkan t tabel 2,011 (2,300 > 2,011), maka dapat disimpulkan bahwa variabel Religiusitas berpengaruh signifikan terhadap keputusan memilih produk gadai emas di PT Bank Syariah Mandiri KCP Medan Iskandar Muda.

\section{Pengaruh Persepsi dan Religiusitas Secara Simultan terhadap Keputusan Nasabah}

Apabila tingkat signifikansi lebih kecil dari 0,05 dan F hitung lebih besar dari F tabel, maka variabel independen berpengaruh secara simultan terhadap variabel dependen. Berdasarkan hasil penelitian ini diperoleh tingkat signifikansi variabel sebesar 0,000 yang artinya lebih kecil dari $0,05(0,000<0,05)$

dan $\mathrm{F}$ hitung sebesar 27,042 lebih besar dibandingkan $\mathrm{F}$ tabel 3,19 (11,132 > 3,19), maka dapat disimpulkan bahwa variabel persepsi dan religiusitas secara simultan berpengaruh signifikan terhadap keputusan memilih produk gadai emas di PT Bank Syariah Medan KCP Iskandar Muda.

Variabel yang Paling Dominan Mempengaruhi Keputusan Memilih Produk Gadai Emas PT Bank Syariah Mandiri KCP Medan Iskandar Muda

Koefisien Determinasi

\begin{tabular}{lccc}
\hline Variabel & $\begin{array}{c}\text { Standarized } \\
\text { Coeficients Beta }\end{array}$ & Correlations & $\mathbf{R}^{\mathbf{2}}$ \\
\hline Persepsi & $\mathbf{0 , 4 2 9}$ & $\mathbf{0 , 6 9 5}$ & $\mathbf{0 , 2 9 8}$ \\
Religiusitas & $\mathbf{0 , 3 5 0}$ & $\mathbf{0 , 6 7 6}$ & $\mathbf{0 , 2 3 6}$ \\
\hline
\end{tabular}

Berdasarkan tabel di atas maka dapat diperoleh hasil sebagai berikut:

1. Persepsi

Nilai koefisien determinasi menunjukkan seberapa besar variabel independen menjelaskan/mempengaruhi variabel dependen. Nilai $R$ Square sebesar 0,298 menunjukkan bahwa variabel persepsi mampu menjelaskan atau mempengaruhi keputusan memilih sebesar 29,8\% sedangkan sisanya sebesar 70,2\% dipengaruhi oleh variabel lain. 
2. Religiusitas

Nilai koefisien determinasi menunjukkan seberapa besar variabel independen menjelaskan/mempengaruhi variabel dependen. Nilai $R$ Square sebesar 0,236 menunjukkan bahwa variabel nilai taksiran mampu menjelaskan atau mempengaruhi keputusan memilih sebesar 23,6\% sedangkan sisanya sebesar 76,4\% dipengaruhi oleh variabel lain.

Berdasarkan pembahasan di atas, maka dapat disimpulkan bahwa variabel dengan nilai koefisien determinasi yang paling tinggi adalah variabel persepsi yaitu sebesar 29,8. Dengan demikian, variabel yang paling dominan mempengaruhi keputusan memilih produk gadai emas pada Bank Syariah Mandiri KCP Medan Iskandar Muda adalah variabel persepsi.

\section{KESIMPULAN}

Berdasarkan analisis data dan pembahasan yang telah dilakukan yang mengacu pada masalah dan tujuan penelitian, maka dapat diambil kesimpulan sebagai berikut:

1. Variabel persepsi mempunyai pengaruh yang signifikan dan positif terhadap keputusan memilih produk gadai emas di PT. Bank Syariah Mandiri KCP Medan Iskandar Muda

2. Variabel nilai religiusitas mempunyai pengaruh yang signifikan dan positif terhadap keputusan memilih produk gadai emas di PT. Bank Syariah Mandiri KCP Medan Iskandar Muda

3. Variabel persepsi dan religiusitas secara simultan mempunyai pengaruh yang signifikan dan positif terhadap keputusan memilih produk gadai emas di PT. Bank Syariah Mandiri KCP Medan Iskandar Muda, dan variabel yang paling dominan mempengaruhi keputusan memilih produk gadai emas di PT. Bank Syariah Mandiri KCP Medan Iskandar Muda adalah persepsi, dimana nilai $\mathrm{R}$ Square variabel pelayanan adalah sebesar 0,298.

\section{DAFTAR PUSTAKA}

Al-Qur'an Departemen Agama RI. 2009. Al-Qur'an dan Terjemahannya.

Surabaya: CV Assalam Surabaya.

Afriana, Arifah. 2016. Pengaruh Nilai Taksiran Dan Biaya Ijarah Terhadap Keputusan Nasabah Melakukan Gadai Emas Di Pengadaian Syariah Cabang Abdullah Dg.Sirua Makassar. Skripsi. Fakultas Ekonomi dan Bisnis Islam. Universitas Islam Negeri Alauddin. Makassar.

Amir, M Taufiq. 2014. Merancang Kuesioner. Jakarta: Prenadamedia Group 
Andriani, Ayu. 2015. Pengaruh Persepsi dan Religiusitas Santri Terhadap Minat Menabung di Perbankan Syariah(Studi Kasus di Pondok Pesantren AlFalah Mojo Kediri). Skripsi. IAIN Tulung Agung.

Arikunto, Suharsimi. 2016. Prosedur Penelitian Suatu Pendekatan Praktik. Jakarta: Rineka Cipta.

Asro, Muhammad dan Muhammad Khalid. 2011. Fiqh Perbankan. Jakarta: Pustaka Setia.

Dewan Syariah Nasional. 2002. Fatwa Dewan Syariah Nasional No. 25/ DSNMUI/III/2002 tentang Rahn.

Dewan Syariah Nasional. 2002. Fatwa Dewan Syariah Nasional No. 26/ DSNMUI/III/2002 tentang Rahn Emas.

Ghozali, Imam. 2017 Aplikasi Analisis Multivariete Dengan Program IBM SPSS 23. Semarang: Badan Penerbit Universitas Diponegoro.

Ismail. 2015. Perbankan Syariah. Surabaya: Prenada Media Grup.

Jalaluddin. 2010. Psikologi Agama. Jakarta: PT Raja Grafindo Persada.

Maski, Ghozali. 2010. Analisis Keputusan Nasabah Menabung: Pendekatan Komponen Dan Model Logistik Studi Pada Bank Syariah Di Malang. Jurnal Vol. 4, No. 1. Hal. 43-57. Journal Of Indonesian Applied Economics.

Masruroh, Atik. 2015. Analisis Pengaruh Tingkat Religiusitas Dan Imposible Income Terhadap Minat Menabung Mahasiswa Di Perbankan Syariah. Skripsi. Program Studi Perbankan Syariah. Sekolah Tinggi Agama Islam Negeri Salatiga.

Muslim, Bukhori. 2011. Pembiayaan Gadai Emas Pada Bank Syariah Mandiri Cabang Bekasi. Skripsi. Fakultas Syariah dan Hukum. Universitas Islam Negeri Syarif Hidayatullah. Jakarta.

m.kontan.co.id diunduh pada tanggal 2 Juni 2019

Nashori, Fuad dan Mucharam. 2002. Mengembangkan Kreativitas Dalam Perspektif Psikologi Islami. Yogyakarta: Menara Kudus.

Ningsih, Julia S. 2017. Pengaruh Persepsi, Tingkat Religiusitas, Dan Disposable Income Terhadap Minat Menabung Di Perbankan Syariah. Skripsi. Fakultas Ekonomi dan Bisnis Islam. Universitas Islam Negeri Raden Intan. Lampung.

Priyatno, Duwi. 2012. Cara Kilat Belajar Analisis Data Dengan SPSS 20. Yogyakarta: Andi.

Perdana, Andri. 2018. Analisis Pengaruh Ujroh, Nilai Taksiran Dan Pelayanan Terhadap Keputusan Nasabah Untuk Melakukan Take Over Gadai Emas Pada Bank Syariah Mandiri Kcp Medan Iskandar Muda. Skripsi. Program Studi Keuangan dan Perbankan Syariah. Politeknik Negeri Medan.

Sandrakh, Geralda. 2013. Analisis Pengaruh Penilaian Konsumen Pada Minat Beli Terhadap Keputusan Pembelian Produk Private Label. Fakultas Ekonomika dan Bisnis. Universitas Diponegoro. Semarang.

Sangadji, Mamang Etta dan Sopiah. 2013. Perilaku Konsumen Pendekatan Praktis Disertai Himpunan Jurnal Penelitian. Yogyakarta: CV Andi Offset

Sanusi, Anwar. 2011. Metodologi Penelitian Bisnis. Jakarta Selatan: Salemba Empat. 
Setiadi, Nugroho J. 2013. Perilaku Konsumen: Perspektif Kontemporer Pada Motif, Tujuan, dan Keinginan Konsumen. Jakarta: Prenada Media Grup.

Setiawan, Dwi Endah Kusrini. 2010. Ekonometrika. Yogyakarta: CV Andi Offset.

Shofwa, Yoiz. 2017. Pengaruh Kualitas Produk dan Religiusitas Terhadap Keputusan Nasabah Produk Simpanan Pada BSM Cabang Purwokerto. Fakultas Ekonomi dan Bisnis Islam. Jurnal. Fakultas Ekonomi Dan Bisnis Islam. Institut Agama Islam Negeri Purwokerto.

Sthepen, Robbins. 2015. Perilaku Organisasi=Organizational Behavior. Jakarta: Salemba.

Sudarsono, Heri. 2014. Konsep Ekonomi Islam Suatu Pengantar. Yogyakarta: EKONISI

Sugiyono. 2017. METODE PENELITIAN Kuantitatif, Kualitatif, dan R\&D. Jakarta: Alfabeta.

Sujarweni, V Wiratna. 2016. Kupas Tuntas Penelitian Akuntansi dengan SPSS. Yogyakarta: Pustaka Baru Press

Suryani, Hendryadi. 2014. Metode Riset Kuantitatif Teori dan Aplikasi Pada Penelitian Bidang Manajemen dan Ekonomi Islam. Jakarta: Kencana.

Tri Basuki, Agus dan Nano Prawoto. 2016. Analisis Regresi dalam Penelitian Ekonomi dan Bisnis. Jakarta: Rajawali Pers.

Umam, Khaerul. 2011. Manajemen Perbankan Syariah. Bandung: Pustaka Setia.

Undang-Undang Nomor 21 Tahun 2008, tentang Perbankan Syariah.

Wibowo, R. Ery. 2014. Analisis Religiusitas, Pemahaman Produk dan Sistem Pembiayaan Syariah dengan Sikap Pengusaha. Jurnal. Fakultas Ekonomi., Universitas Muhammadiyah Semarang.

Wibowo. 2015. Perilaku Dalam Organisasi. Jakarta: Rajawali Pers.

www.iqtishadconsulting.com diunduh pada tanggal 2 Juni 2019

Zainal, Veithzal R. 2014. Kepemimpinan Dan Perilaku Organisasi. Jakarta: PT Raja Grafindo Persada.

Zuhirsyan, Muhammad dan Nurlinda. 2018. Pengaruh Religiusitas Dan Persepsi Nasabah Terhadap Keputusan Memilih Bank Syariah. Jurnal. Amwal Vol. 10 No. 1 IAIN Syekh Nurjati Cirebon. 